I. Soc. Cosmet. Chem. Jpn.

$\left[\begin{array}{lll}\text { 総 } & 535-545 & (1994)\end{array}\right]$

\title{
香粧品洗浄剂と皮虐生理
}

\author{
須貝哲郎 \\ 大阪回生病院皮膚科

\section{Effects of Cleansers in the Cosmetic and Toiletry Field on Skin physiology}

\author{
Tetsuro Sugai
}

Department of Dermatology, Osaka Kaisei Hospita1*

\begin{abstract}
Skin safety of cleansing products in the cosmetic and toiletry field has been much more improved than the previous ones. However, patients with overtreatment dermatitis are sometimes seen at our clinic. Friction melanosis is a representative overtreatment dermatosis. Most of overtreatments in patients with atopic dermatitis are everyday's shampooing, especially in the morning. It is necessary to make a proper skin care, depending on the individual skin condition.
\end{abstract}

\section{1. はじめに}

香粧品洗浄剂は顔面だけでなく，全身の皮膚， 頭髪および口腔内を清潔にすることを目的とする すべての製剤を含む。したがって，石䲓およびボ ディシャンプー, クレンジングフォームと洗顔石 鹼, 歯磨および口腔清浄剤を対象としてその使用 の皮膚に及ぼす生理学的影響を述べる。

\section{2. 界面活性荗と皮局}

洗浄剤は皮表や頭髪に付着した埃（ほこり）, 細 菌真菌類および分解された汗や皮脂を洗い流すた めに，すべての製剤に有効濃度の界面活性剤が含 まれている。口腔洗浄剤も同じである。したがっ て，洗浄剂と皮膚生理といらタイトルはそのまま 界面活性剤の皮膚に及ぼす影響といらタイトルに 置き換えても差支えないと思う。

界面活性剂は油脂類を水に溶解させる作用を有

† 531 大阪市北区豊崎4-6-6; 4-6-6 Toyosaki, Kita-ku, Osaka 531, Japan
し，皮表の古い皮脂を洗い流して皮膚を清潔にす るのだが，同時に皮膚の外界刺激に対する防御能 を司る皮脂膜を破壊する。このため洗浄作用の強 い界面活性剂汪ど皮膚刺激性が強く, 皮膚に障害 を与光，慢性刺激性接触皮膚炎を生じやすい。

古典的な sodium lauryl sulfate (SLS) は陰 イオン界面活性剤の代表であり，かってシャンプ 一主成分として用いられ，今も業務用シャンプー や歯磨に使用されているが，現在は皮膚刺激物質 の代表としてヒト maximization testにおける 刺激反応惹起や非破壊生体計測器による測定時の 刺激反応の目安として繁用されている。

陽イオン界面活性剂は一般に皮膚刺激性の高い ことで知られ，その代表である benzalkonium chloride (BZC) は Draize 家鬼眼球刺激テスト の対照として用いられているが，その使用により 頸部魚鱗痽様皮膚炎と命名された慢性刺激性接触 皮膚炎を多数発生させたことは有名な出来事であ る1)。強い殺菌能を有するので, 現在も消毒薬と して医家向けに広く用いられ, 点眼薬の防腐剤と 
しても含有されているが，濃度を誤ると容易に刺 激性皮膚炎を生ずる(Fig.-1)。

両性界面活性剂の代表である acylglutamate (AGS) は残留刺激性が強く，いつとはなく皮膚 の乾燥化をきたすが2)，おそらく陽イオン界面活 性剂と同様に陽イオン基 $\mathrm{NH}_{2}$ がケラチンと結合 し，残留刺激を示すのであろら。

最近, 使用されている N-coconut-1-glutamic acid triethanolamide 友膚刺激性は低く

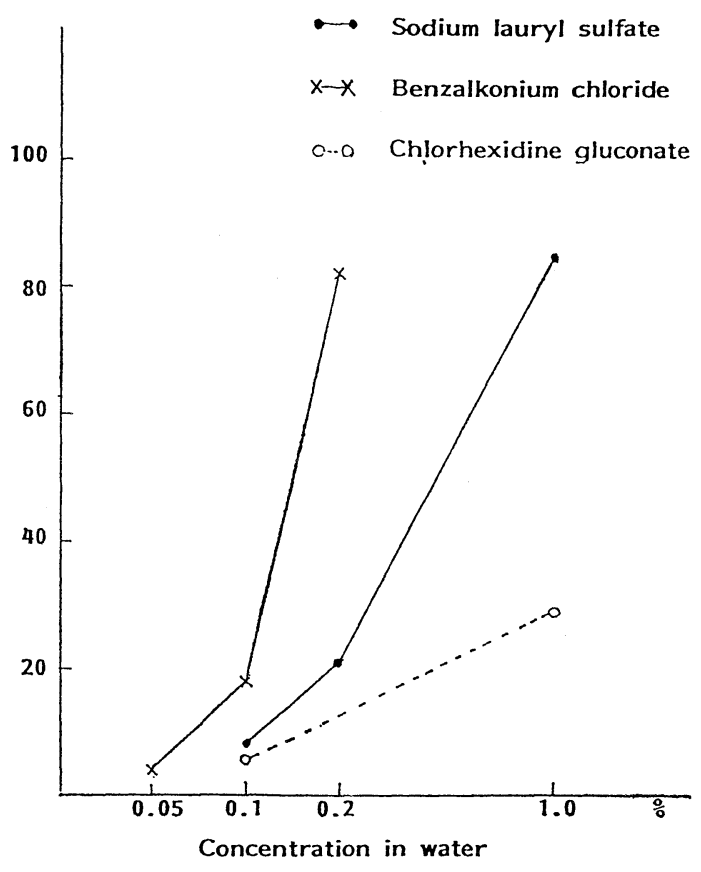

Fig.-1 Relationship between Skin Irritation Index and Concentration of Representative Detergents $(\mathrm{N}=25)$
なっているが，残留刺激性があるようで，0.9\% 濃度での残留刺激指数は 13.3 , 残留刺激率 $72.7 \%$ であった (Table-1) $)^{3)}$ 。

古くから広く用いられているボディ洗浄剤の石 鹼はその純度が高くなり，刺激性の強い lauric acid 含有量が低下しているにもかかわらず,パッ チテストは $1 \%$ 水溶液で施行せ齐ばならない4。 最近のボディシャンプーが $10 \%$ 水溶液でも低い皮 膚刺激指数を示す製剂のあることから，脂肪酸》 一ダよりも皮膚安全性の高い界面活性剤が出現し たと推定されるのだが，洗浄力がよくて皮虐刺激 性の低い界面活性剤なのかどうかは不明である。

\section{3. ボディ洗浄剤と皮虐生理}

ボディ洗浄剤の代表は石瞼であり，その歴史も 古い。科学の進歩とともにその純度も増し，皮膚 刺激性も低くなったが5)，脂肪酸ソーダの皮膚刺 激性低下をこれ以上望むのは無理かもしれない。

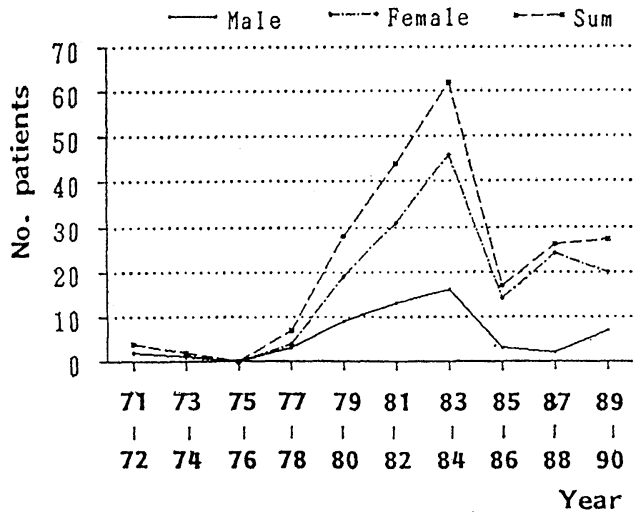

Fig.-2 Annual Variation in Patients with Friction Melanosis (1971-1990)

Table-1 Delayed Skin Irrition Index of Amphoteric Detergents

\begin{tabular}{|c|c|c|c|c|c|c|}
\hline Test material & No. tested & Score & $\begin{array}{l}\text { Skin } \\
\text { irritation } \\
\text { index }\end{array}$ & $\begin{array}{l}\text { Delayed } \\
\text { irritation } \\
\text { score }\end{array}$ & $\begin{array}{l}\text { Delayed } \\
\text { irritation } \\
\text { ratio }(\%)\end{array}$ & $\begin{array}{l}\text { Delayed } \\
\text { irritation } \\
\text { index }\end{array}$ \\
\hline $\begin{array}{l}\text { AGS soap } \\
\quad(1 \% \text { aqueous solution })\end{array}$ & 113 & 41.5 & 36.7 & 37.0 & 89.2 & 32.7 \\
\hline $\begin{array}{l}\mathrm{N} \text {-coconut-1-glutamic acid } \\
\text { triethanolamine } \\
(0.9 \% \text { aqueous solution })\end{array}$ & 30 & 5.5 & 18.3 & 4.0 & 72.7 & 13.3 \\
\hline
\end{tabular}


日本人の多くが毎日入浴し，全身を石醶のつい たタオルで摩擦するといら過激なボディケアをし ているにもかかわらず，石嬐によると思われる慢 性型刺激性接触皮膚炎は汪とんどなかった。ナイ ロンタオルやボディブラシの併用で初めて摩擦黒 皮症の出現をみたのだが (Fig.-2), ナイロンタオ ルは以前から使用されていたにもかかわらず，摩 擦黒皮症が急増したのは 1979 年からで, 1983〜 1984 年にピークに達し, その後約 $1 / 3$ に減少し ている。これは居住環境が今までの開放型からア ルミサッシの普及により密閉型に変化した時期に 一致している $(\text { Fig. - 3 })^{6)}$ 。同じ現象はホルマリン 皮膚炎患者 $(\text { Fig. }-4)^{7)}$, 老人性乾皮症 $(\text { Fig. }-5)^{8)}$,

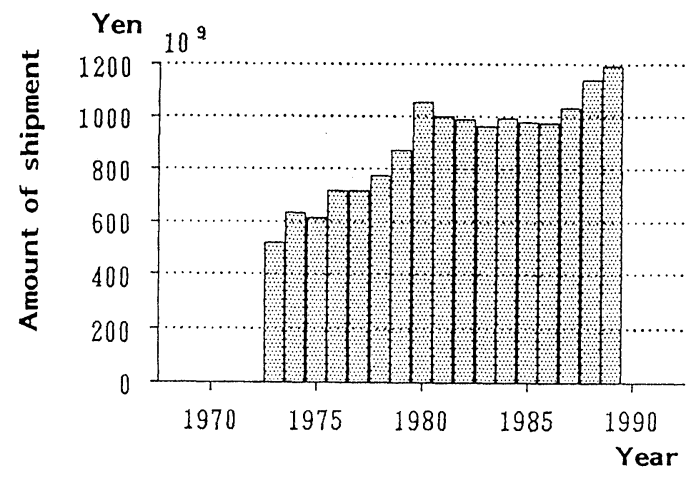

Fig.-3 Annual Amount of Shipment of Aluminum Doors and Window-Frames

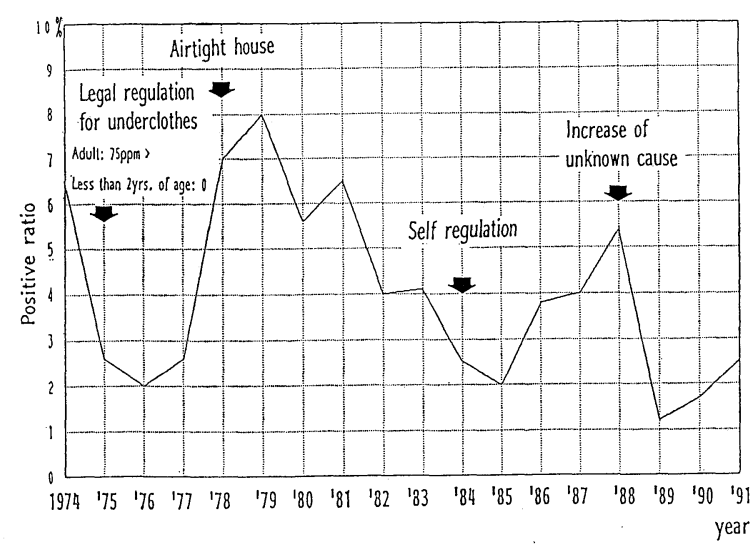

Fig.-4 Annual Variations of the Incidence of Positive Reactions to Formaldehyde in Patch Tests
さらにはアトピー性皮䖉炎にもみられた（Fig.6) ${ }^{9)}$ 。

香粧品洗浄剂, 特にボディ洗浄剤と皮虐との関 係を研究する場合に重要なポイントは皮膚乾燥化 を生ずる因子が多数あるということである。

Table-2 に乾皮症ないし皮脂減少性皮膚炎と その関連疾患の因果関係を示す8)。

アルミサッシとエアコンディショナーの普及に よる低湿度環境の他に, 高齢化社会の到来, 密着 肌着の定着, 毎日シャンプー(いわゆる朝シャン) の流行など，皮膚乾燥化をきたす因子がすべて出 そろっている。

住環境だけでなく, 衣料環境も慢性刺激性接触

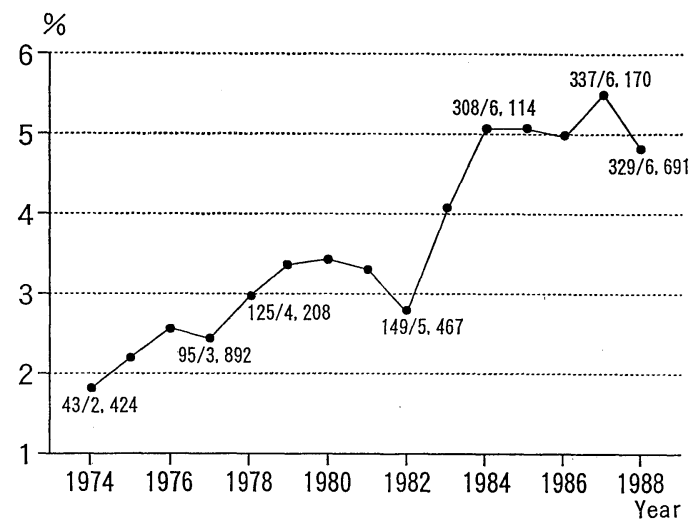

Fig.-5 Annual Variations of the Incidence of Patients with Senile Xerosis

The number shows patients with senile xerosis to the whole patients.

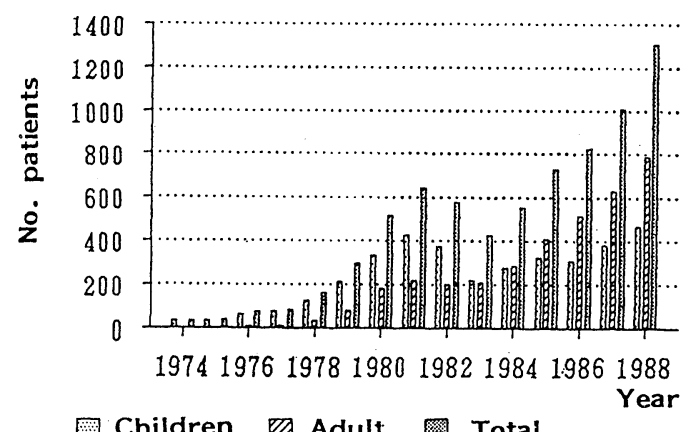

Fig.-6 Annual Variations of Atopic Patients 
Table-2 The Causes of Asteatotic Dermatitis and Its Related Dermatoses

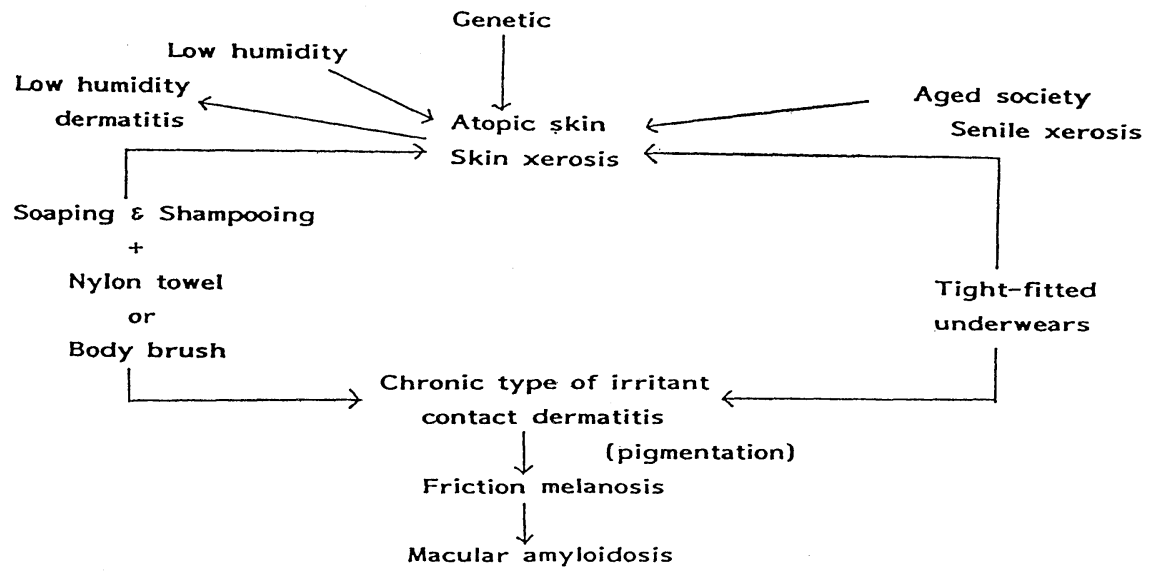

皮膚炎の発症に役割を演ずる時代となっている。 1980年は, わが国の住環境が大きく変化した画 期的な年といえるであろら。この変化に伴って摩 擦黒皮症が出現増加し，今までみらなかった石 鹼皮膚炎やシャンプー皮膚炎がみられるようにな り，特に後者は20歳未満の人々に急増した。その 上, 成人型アトピー性皮膚炎が1985年来, 急增して その年齢分布が欧米型の 2 峯性となった（Fig.7) ${ }^{9)}$ 。

1980年以前は事実上, 小児アトピー性皮膚炎だ けしかなく，その年齢分布は 1 峯性で20歳を過ぎ れば，自然に軽快するからと励ましていたのに， 現在では，16歳頃から発症し，20歳前後の患者が 最も多くなっている。

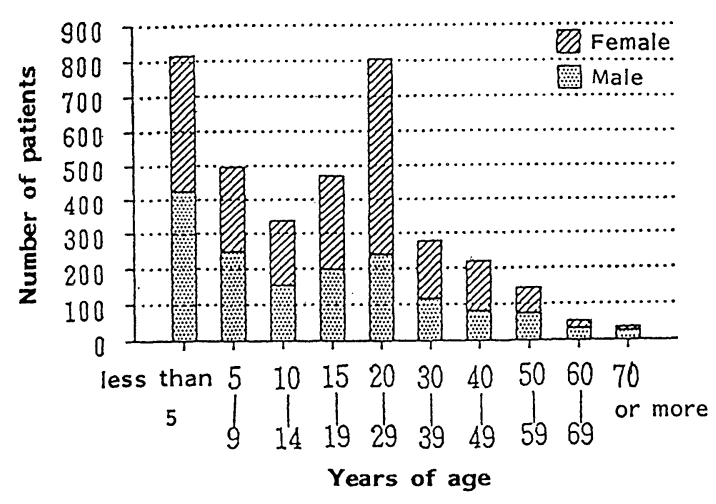

Fig.-7 Age and Sex Distribution of Atopic Patients Seen in 1983 to 1988
Fig.-8 は著者が 1983 年, サンフランシスコで 開催された IFSCC 中間大会で年齢層を代表する 3 皮膚疾患として発表したものだが10)，アトピー 性皮膚炎が老人性乾皮症に対応する乾燥性皮膚疾 患であるといら基本的な考え方に今も変わりはな

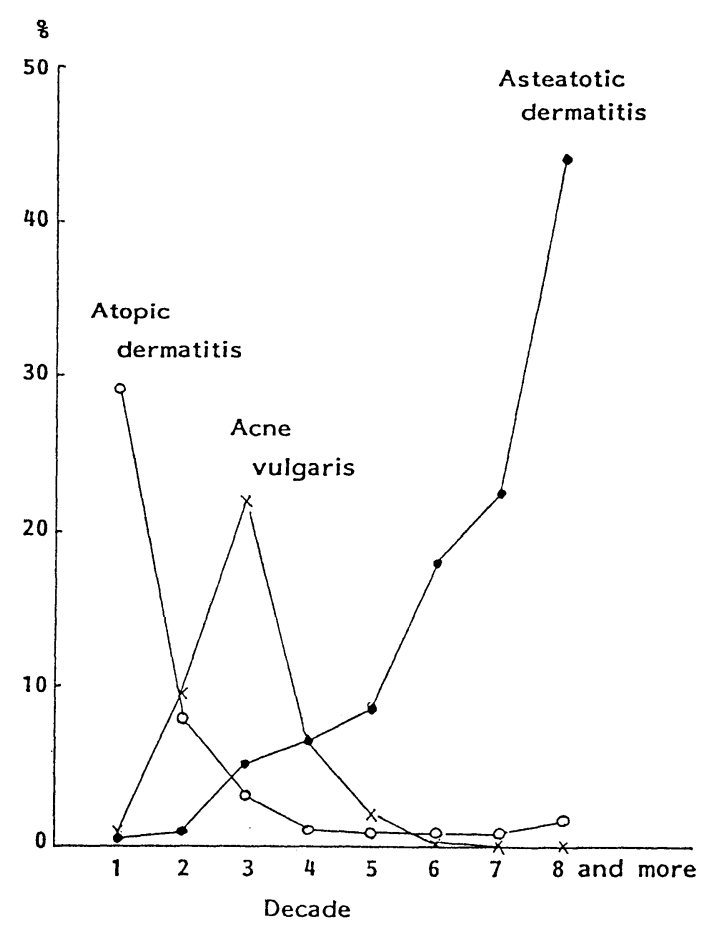

Fig.-8 Age Distribution of Age-Dependent Dermatoses 
い。2 歳までの小览アトピー性皮覤炎患者に食餌 アレルギーの関与があるように成人型アトピー性 皮膚炎患者では air-borne allergenないし irritant の関与があり，それが顔面湿疹の繰り返し につながっていると推定している。

重要なのは低湿度環境, 高㱓化社会, 密着肌着, アトピー性皮膚炎患者の急増など重複する悪条件 下でも使用しらる, 安全なボディ洗浄剤が要求さ れているといらことである。特に，アトピー性皮 膚炎患者でも使用しらるボディ洗浄剤をつくりら るかどらかは，皮膚科医にとって最も重要な課題 の一つである。今回の講演の主旨から外れること になるが，少なくとも10歳未満の幼少児に毎日使 用できるボディ洗浄剤は現在の界面活性剂化学の 進歩により可能になったと思 ${ }^{31}$ 。

\section{1 小児皮䖈の特殊性}

10歳未満の小児の皮膚は皮脂分泌が皃とんどな く, 未熟で薄いために, 成人皮膚よりも外界刺激 に対する耐容性が有意に低く ${ }^{11)}$ ，特に石鹼シャン プーなどの界面活性剤によって容易に乾燥化をき たす3),10),12)。皮膚の乾燥，毛孔性ないし汗口性 角化性丘疹, 白色皮膚描記（皮膚を擦過すると， その部が白色を呈する現象）および汗の皮内貯留 （アセモができやすい状態）を総称してアトピー 性皮膚とよんでいるが，アトピー性皮膚を有する 小児がすべてアトピー性皮膚炎とは限らない。む しろその半数は主として母親の誤ったボディケ ア，毎日，入浴時に石醶で全身を洗い流すという 過剰手入れによって生じた母原病といってょく (overtreatment dermatitis)，いわゆる小児乾
燥性皮膚炎に該当する。石鹼の使用と擦過を控兄 させ，保湿剤およびワセリンを外用させるだけ で，痋痒が消失し，数力月後に正常皮膚に戻る。 放置していても，軽症な例は10歳頃から皮脂の分 泌が始まり, 皮膚も成熟して厚くなるとともに, dry skin はしだいに消失し，尋常性痤瘡を生じ やすくなる。

小児の経皮吸収率は成人より有意に高く, 代表 的な金属イオンである $\mathrm{Ni}^{++}, \mathrm{Co}^{++}$および $\mathrm{Cr}^{6+}$ のパッチテストを標準濃度のそれぞれ $2.5 \%, 1 \%$ および $0.5 \%$ ワセリンで行らと，10歳未満児では 偽陽性を呈する頻度が有意に高い(Table-3) ${ }^{11)}$, 12)。

\section{2 ボディ洗浄剤の皮膚安全性}

ヒトに打ける皮膚安全性を評価する方法はいく つかあるが，今のところ，予知パッチテストより 優れる方法はないと思う5)。

ボディ洗浄剤の代表である石略のパッチテスト は $1 \%$ 水溶液で行うのが刺激性評価に最も適し ているが，ボディシャンプー製剤は石齢タイプを 除き，as is および $10 \%$ 水溶液がよいと思う

\section{(Table-4)。}

界面活性剂の皮膚安全性が向上してきたので, 市販製剂の安全性評価を行らのに，1\%ではすべ て安全品となり，10\%濃度でその差が判定できる からである。

患者の持参した種々の市販石畧の皮膚刺激性も この10年間で著しく低下し，1975-1976年では刺 激指数51.4だったのに，1984-1986年には12.8に なっている5

Table-3 Comparison of Patch Test Reactions to lons of Chrome, Cobalt and Nickel in Age Groups

\begin{tabular}{|c|c|c|c|c|c|c|c|c|c|c|c|c|}
\hline Age (yrs.) & \multicolumn{3}{|c|}{$9 \geq$} & \multicolumn{3}{|c|}{$10-19 \geq$} & \multicolumn{3}{|c|}{$20 \leq$} & \multicolumn{3}{|c|}{ Total } \\
\hline Patch test & No.tested & No.pos. & $\%$ & No.tested & No.pos. & $\%$ & No.tested & No.pos. & $\%$ & No.tested & No.pos. & $\%$ \\
\hline Chrome ion & 119 & 16 & 13.4 & 488 & 17 & 3.5 & 5,237 & 421 & 8.0 & 5,844 & 454 & 7.8 \\
\hline Cobalt ion & 117 & 22 & 18.8 & 487 & 38 & 7.8 & 5,184 & 546 & 10.5 & 5,788 & 606 & 10.5 \\
\hline Nickel ion & 94 & 14 & 14.9 & 481 & 17 & 3.5 & 5,076 & 472 & 9.3 & 5,651 & 503 & 8.9 \\
\hline
\end{tabular}

In apparently allergic reactions: 9 yrs. or less $>10-19$ yrs. (Significant at a level of 0.01 ) Most of positive reactions in less than 10 years group is considered to be false positive. 


\section{粧 技 誌 第27巻第 4 号 1994}

Table-4 Total and Delayed Skin Irritation Index of Commercial Body Shampoos

\begin{tabular}{|c|c|c|c|c|c|c|c|}
\hline \multirow{2}{*}{ Material } & \multirow{2}{*}{ Concentration } & \multirow{2}{*}{$\begin{array}{l}\text { No. } \\
\text { tested }\end{array}$} & \multicolumn{2}{|c|}{ Total irritation } & \multicolumn{2}{|c|}{ Delayed irritation } & \multirow{2}{*}{$\begin{array}{l}\text { Allergic } \\
\text { reaction }(\%)\end{array}$} \\
\hline & & & Score & Index & Score & Index & \\
\hline \multirow{3}{*}{ A } & as is & & 4.5 & 15.5 & 2.0 & 6.9 & \\
\hline & $10 x$ & 29 & 0.5 & 1.7 & 0.0 & 0.0 & $1(3.3 \%)$ \\
\hline & $100 x$ & & 0.5 & 1.7 & 0.5 & 1.7 & \\
\hline \multirow{3}{*}{$\mathrm{B}$} & as is & & 3.5 & 12.1 & 2.5 & 8.6 & \\
\hline & $10 x$ & 29 & 2.0 & 6.9 & 1.0 & 3.4 & $1(3.3 \%)$ \\
\hline & $100 x$ & & 0.0 & 0.0 & 0.0 & 0.0 & \\
\hline \multirow{3}{*}{$\mathrm{C} *$} & as is & & 37.5 & 125.0 & 28.5 & 95.0 & \\
\hline & $10 x$ & 30 & 13.5 & 45.0 & 6.0 & 20.0 & $0(0.0 \%)$ \\
\hline & $100 x$ & & 1.0 & 3.3 & 0.0 & 0.0 & \\
\hline
\end{tabular}

* Soap type

し，1990年 9 月～1991年 8 月の 1 年間の成績では 4. 3で15), かつて班研究で, いわゆる低刺激性石醶 の皮膚刺激指数を検討したデータと比べて ${ }^{16)}$, 一 般の市販石醶の平均刺激指数がそれよりも低く， もはやわざわざ低刺激性石醶と称する必要がなく なったといえる（Table-5）。

著者には，どのような組成の変更が行われたか を知る由もないが， $1 \%$ 水溶液で皮膚刺激指数 5.0 以下の石險が一般化したことは確かで誠に喜ばし い限りである。

他方, 液体型のボディ洗浄剂が若い人々の間に
人気があり, 続々と新製品が市場に出ているが, 石䲓タイプのボディ洗浄剂より新しい界面活性剂 を主成分とするボディシャンプーの方がさらに皮 膚刺激性が低く，アトピー性皮膚炎患者に使用さ せらるし，その使用方法により皮疹の改善をみる 製剤のあることも明らかになっだ4,17)。

\section{4. 頭髪洗浄剂}

頭髪は脂腺が発達し, 皮脂分泌も多く, 界面活 性剂による脱脂に伴ら皮膚乾燥の回復が早いの で，皮膚刺激指数のかなり高い，洗浄効果の強い

Table-5 Annual Changes of Skin Irritation Index in Various Soaps

\begin{tabular}{|c|c|c|c|c|c|c|c|}
\hline \multirow{2}{*}{ Material } & \multirow{2}{*}{ Year tested } & \multirow{2}{*}{$\begin{array}{l}\text { No. } \\
\text { tested }\end{array}$} & \multicolumn{2}{|c|}{ Total irritation } & \multicolumn{2}{|c|}{ Delayed irritation } & \multirow{2}{*}{ Judgment* } \\
\hline & & & Score & Index & Score & Index & \\
\hline Various soaps & $1975-1976$ & 106 & 54.5 & 51.4 & - & - & $x$ \\
\hline which patients & $1984-1986$ & 125 & 16.0 & 12.8 & - & - & 0 \\
\hline brought & $1990-1991$ & 94 & 4.0 & 4.3 & 4.0 & 4.3 & (a) \\
\hline Arginine sugar soap & 1987 & 102 & 10.5 & 10.3 & 6.0 & 5.9 & 0 \\
\hline TEA soap & 1987 & 102 & 27.0 & 26.5 & 16.5 & 16.2 & $\triangle$ \\
\hline AGS soap & 1987 & 102 & 31.5 & 30.9 & 27.0 & 26.5 & $\triangle$ \\
\hline SLS soap & 1987 & 113 & 101.5 & 89.8 & 81.0 & 71.7 & $x$ \\
\hline Liquid soap & 1992 & 30 & 1.0 & 3.3 & 0.0 & 0.0 & (a) \\
\hline
\end{tabular}

The whole materials were patch-tested at a $1 \%$ aqueous solution.

* TEA: Triethanolamine, AGS: acyl glutamic acid sodium, SLS: sodium lauryl sulfate.

(Q) : Safe product, $\bigcirc$ : permissible product, $\triangle$ : product needed improvement, $x$ : risk product to cause dry skin. 
製剂にも耐兄らる。脂性肌ないし脂漏性皮膚を有 する人々では洗髪後数時間で皮脂過剩になるよう な例子あり，皮膚常在菌の増殖から脂漏性皮膚炎 や感染性皮膚炎を発症しやすい(Fig.-9)。

いわゆるフヶ(頭部粈糠疹)は脂漏(seborrhea) に伴って出現する油性のもので，暗褐色，粘稠性 のもの（油性脂漏, seborrhea oleosa）を意味 するのだが（Fig.-10），いつの間にか，頭皮の乾 燥によって生ずる鱗原も含むようになり，乾性脂 漏（seborrhea sicca）という奇妙な名称でよば れている。しかし，両者はスキンケアがまったく 異なるので，厳密に区別すべきである。

油性脂漏の場合はいわゆるフケとりシャンプー の適応対象で, zinc pyrithione や Irgasan DP-300®のようなデオドラントを含有する製剤

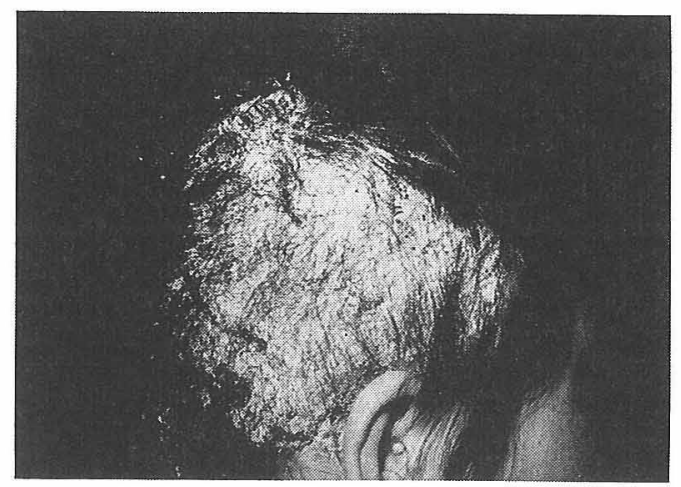

Fig. -9

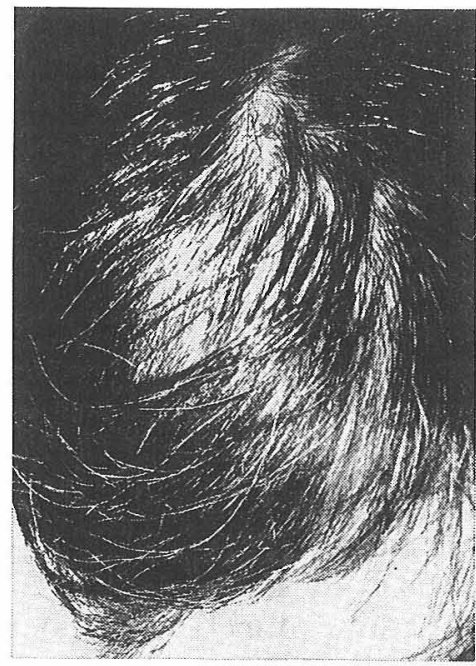

が有効で，さらには硫化セレン含有シャンプーの 使用を必要とする例さえある。

逆に，乾性脂漏(両肩にパラパラと落らるフケ) の場合は，頭皮の乾燥を示す一症状なので，シャ ンプーの使用を控え，頭皮に保湿剤ないし油性の エモリエント剤を塗布せねばならない。

テレビの宣伝効果により，若い人たらが毎日シ ャンプーを行い，時には 1 日 2 回シャンプーをす る例さえみられるようになったが，シャンプー製 珮の皮膚刺激性が低くなったこともあって，過剩 手入れによるシャンプー皮覤炎は問題になるほど は增加していない。

頭皮にシャンプーの障害をうけるのはアトピー 性皮膚炎患者のみで，正常人に生ずるシャンプー 皮膚炎は，まず手背側の全指中間関節部に始末 り，しだいに全関節部に乾燥性落屑状疹を生じ， 色素沈着をきたすと至る（Fig.-11)。ついで，前 額部から上眼瞼にかけて带状の乾燥性湿疹を生 じ，色素沈着を伴ら例もある(Fig.-12)。水仕事

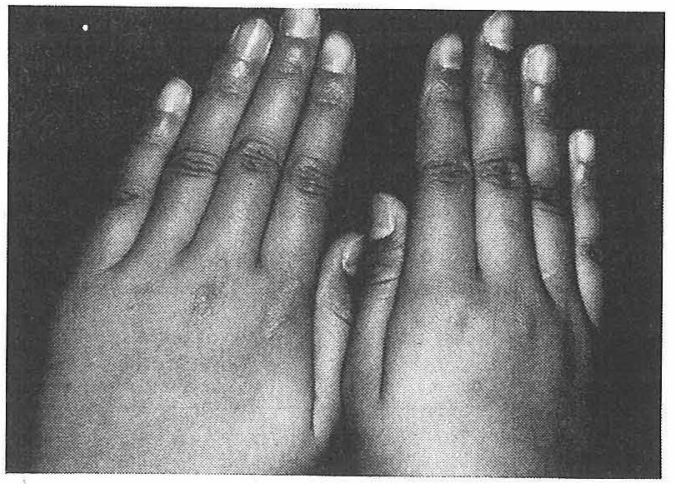

Fig.-11

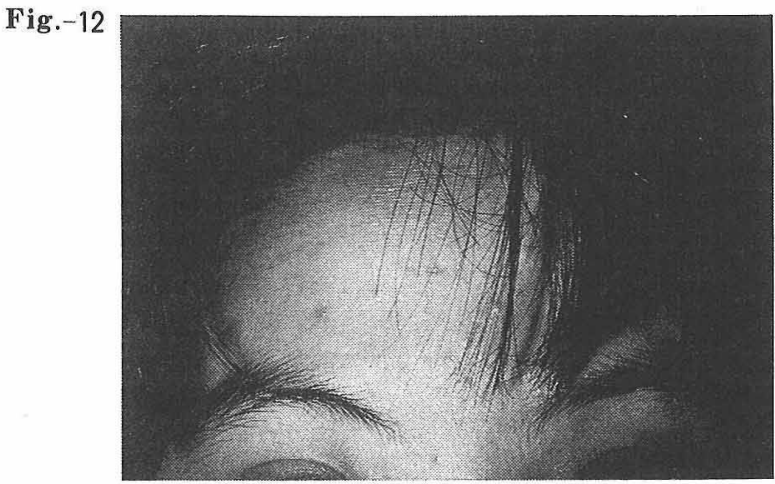

J. Soc. Cosmet. Chem. Japan. Vol.27, No.4 1994 
による手荒れが主として手掌の乾燥をきたすのと 対照的な症状で, かって, ナイロン・ストッキン グを手洗いしていた時代にみられた症状に一致す る ${ }^{18)}$ 。時に前頭部頭髪の断裂もみられ, 前頭部が らすくみえる症例もある。シャンプー製剂も昔よ りはるかに低刺激性になっており（Table-6），乾 性脂漏やアトピー性皮膚炎を有しない限り，障害 を起こすことは少ないようだが，頭皮の状態だけ でなく，ヘアライン周辺の通常皮膚 (glabrous skin）や指背関節部の皮膚所見に注意して, overtreatment にならぬように注意すべきであ る。

\section{5. 化粧品洗浄剤}

クレンジングフォーム, 洗い粉, 洗顔石鹼など, 顔面に用いる洗浄剂に，化粧品を落とすのに用い るクレンジング・クリームないし乳液やジェルを 含めてその皮膚生理に及ぼす影響を述べる。

化粧品を落とす目的のクレンジング製剤は流動 パラフィンを主成分とし，皮膚に油膜をはって，

TEWL を抑制する効果があり, 皮膚の乾燥を防 ぐ。ところが日本女性の多くは油の感触を好ま ず, 洗浄剤 (主として洗顔フォーム) で油の感触 がなくなるまで数回洗顔を繰り返す。この習慣が

Table-6 Total and Delayed Skin Irritation Index of Shampoo Products

\begin{tabular}{|c|c|c|c|c|c|c|c|}
\hline \multirow{2}{*}{ Material } & \multirow{2}{*}{ Year tested } & \multirow{2}{*}{$\begin{array}{l}\text { No. } \\
\text { tested }\end{array}$} & \multicolumn{2}{|c|}{ Total irritation } & \multicolumn{2}{|c|}{ Delayed irritation } & \multirow{2}{*}{$\begin{array}{l}\text { Allergic } \\
\text { reaction (\%) }\end{array}$} \\
\hline & & & Score & Index & Score & Index & \\
\hline Shampoo which & $1975-1976$ & 22 & 14.0 & 63.6 & - & - & $4(18.2)$ \\
\hline Patients brought & $1984-1986$ & 225 & 51.0 & 22.7 & 一 & 一 & $13(5.8)$ \\
\hline ( $1 \%$ aqueous solution) & 1991 & 144 & 14.0 & 9.7 & 10.0 & 6.9 & $2(1.4)$ \\
\hline $\mathrm{HI} 1 \%$ & 1990 & 58 & 4.5 & 7.8 & 4.0 & 6.8 & 0 \\
\hline Medicated Shampoo as is & 1991 & 30 & 2.5 & 8.3 & 1.5 & 5.0 & 0 \\
\hline $1 \%$ & 1991 & 30 & 1.5 & 5.0 & 0.0 & 0.0 & 0 \\
\hline
\end{tabular}

Table-7 Total and Delayed Skin Irritation Index and Allergic Reactions of Cleansing Foams and Creams

\begin{tabular}{|c|c|c|c|c|c|c|c|}
\hline \multirow{2}{*}{ Material } & \multirow{2}{*}{ Year tested } & \multirow{2}{*}{$\begin{array}{l}\text { No. } \\
\text { tested }\end{array}$} & \multicolumn{2}{|c|}{ Total irritation } & \multicolumn{2}{|c|}{ Delayed irritation } & \multirow{2}{*}{$\begin{array}{l}\text { Allergic } \\
\text { reaction }(\%)\end{array}$} \\
\hline & & & Score & Index & Score & Index & \\
\hline \multirow{7}{*}{$\begin{array}{l}\text { Cleansing foam } \\
\text { ( } 1 \% \text { aquesous solution) }\end{array}$} & $1975-1976$ & 55 & 31.5 & 57.4 & - & - & $0(0.0)$ \\
\hline & $1984-1986$ & 231 & 17.0 & 7.4 & - & - & $7(3.0)$ \\
\hline & 1987 & 96 & 13.0 & 14.3 & 8.0 & 8.3 & $1(1.0)$ \\
\hline & 1988 & 114 & 15.0 & 13.9 & 4.0 & 3.5 & $2(1.0)$ \\
\hline & 1989 & 125 & 13.0 & 10.9 & 8.0 & 6.4 & $1(0.8)$ \\
\hline & 1990 & 110 & 11.0 & 10.1 & 8.0 & 7.3 & $1(0.9)$ \\
\hline & 1991 & 112 & 7.0 & 6.3 & 7.0 & 6.3 & $2(1.8)$ \\
\hline \multirow{7}{*}{$\begin{array}{l}\text { Cleansing cream } \\
\text { (as is) }\end{array}$} & $1975-1976$ & 124 & 30.0 & 24.2 & - & - & $0(0.0)$ \\
\hline & $1984-1986$ & 223 & 11.0 & 4.9 & - & - & $2(0.9)$ \\
\hline & 1987 & 73 & 3.0 & 4.1 & 2.0 & 2.7 & $0(0.0)$ \\
\hline & 1988 & 104 & 3.0 & 3.1 & 1.0 & 1.0 & $6(5.8)$ \\
\hline & 1989 & 130 & 5.0 & 3.9 & 4.0 & 2.3 & $2(1.5)$ \\
\hline & 1990 & 144 & 13.0 & 9.1 & 6.0 & 4.2 & $1(0.7)$ \\
\hline & 1991 & 104 & 2.0 & 1.9 & 1.0 & 1.0 & $2(1.9)$ \\
\hline
\end{tabular}


顔面皮膚の乾燥化を促し，外界刺激に対し，無防 備に近い状態をつくっているのだと考える。欧米 の女性がクレンジングクリーム使用後，水洗いだ けでますますのと大きな差である。化粧品メーカ 一の指導書も洗顔料の使用をコースとして入れて いるが，洗顔料の使い方をもっとマイルドにする ように指導する必要があろう。

フェイス・スポンジの併用は尋常性痤瘡のピー リング療法には必要だが，正常肌や乾燥肌には禁 忌である。同様に，角層を削ることを目的とする クレイ粉洗顔も日本女性の多くに皮膚障害を生ず る恐れがある。月に 1 回, 顔剃りをする習慣は日 本女性に特有の習慣であり，日本の女性が同年代 の白人女性よりも界面活性剂に弱い原因の一つと なっている19)。角層は皮膚の外界刺激に対する防 御機能に最も大きな役割を有するので，角層を削 りとって薄くする習慣をなくすることが望まし い。

化粧品洗浄剂の皮膚安全性も他の洗浄剤之同様 にきわめて優れたものになりつつある（Table7)。しかし，アレルギー反応と思われる症例が存 するので注意を要する。

\section{6. 口腔洗浄侴}

口腔粘膜はたえず唾液で洗い流されているため に，界面活性剂の刺激に比較的強い。

口唇紅（唇の紅い部分）に付着した製剤によっ て生ずる慢性刺激性接触口唇炎の臨床型をとるこ とが多い。口唇紅は毛包がなく，エクリン汗腺系 も欠き，独立脂腺のみを有する特殊な部位で，ア レルギー反応を生じても瘙棒を生じない。周辺の glabrous skin に炎症が及ぶと, 初めて痒感を 訴光る。

口腔洗浄剂の代表は歯磨だが，歯磨製剤による 慢性刺激性接触皮膚炎は意外之少ない。しかし， 口唇紅に乾燥落屑を有する患者には，できるだけ 歯磨を使用せぬように，少なくとも歯磨使用後は すぐ口の周囲を水洗いするように指導している。

\section{7. 香粧品洗浄剤中の油脂類の役割}

香粧品洗浄剂には必ず油脂類が添加されている が，界面活性剂による皮表脂質や天然 保 湿因子 (NMF) の減少をどこまで補えるのか疑問であ る。一応, 石䲓シャンプー類は脂性肌用, 乾燥肌

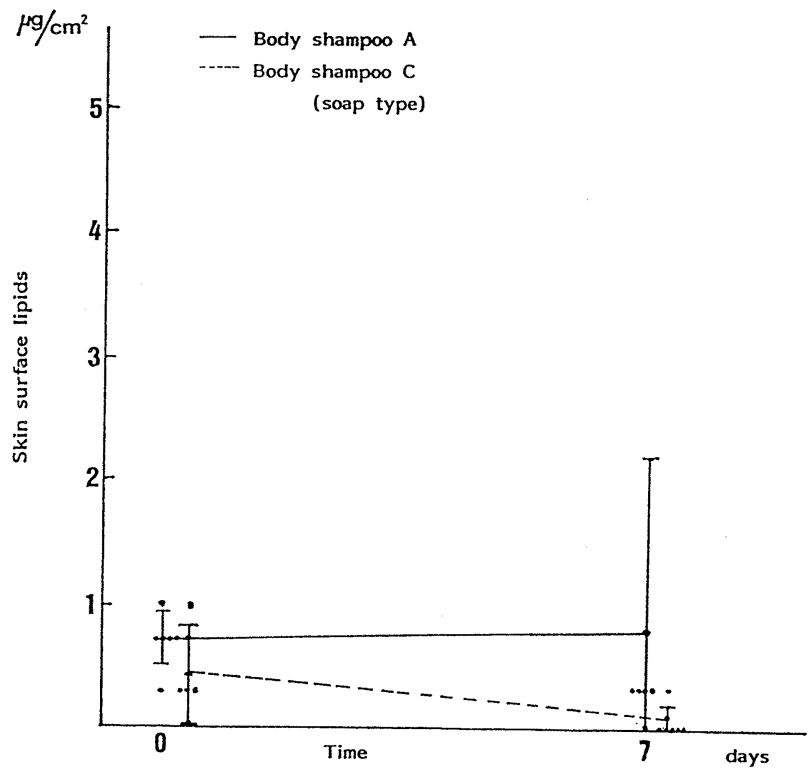

Fig.-13 Changes of Skin Surface Lipids befor and after 1 Week's Use of Two Body Shampoos 
用ないし敏感肌用と表示してある製剤もあるが, 一般にその使用後には皮表脂質の減少, 角層水分 量の低下をみる17)。しかし最近のボディシャンプ 一には 1 週間毎日使用後にも皮脂や角層水分の減
少, TEWL の変動を認めぬ製剤が登場した (Fig.-13〜Fig.-15)。

湯で需らしたスポンジにボディシャンプーをた らし，指でスポンジをもんで生ずる泡を手のひら

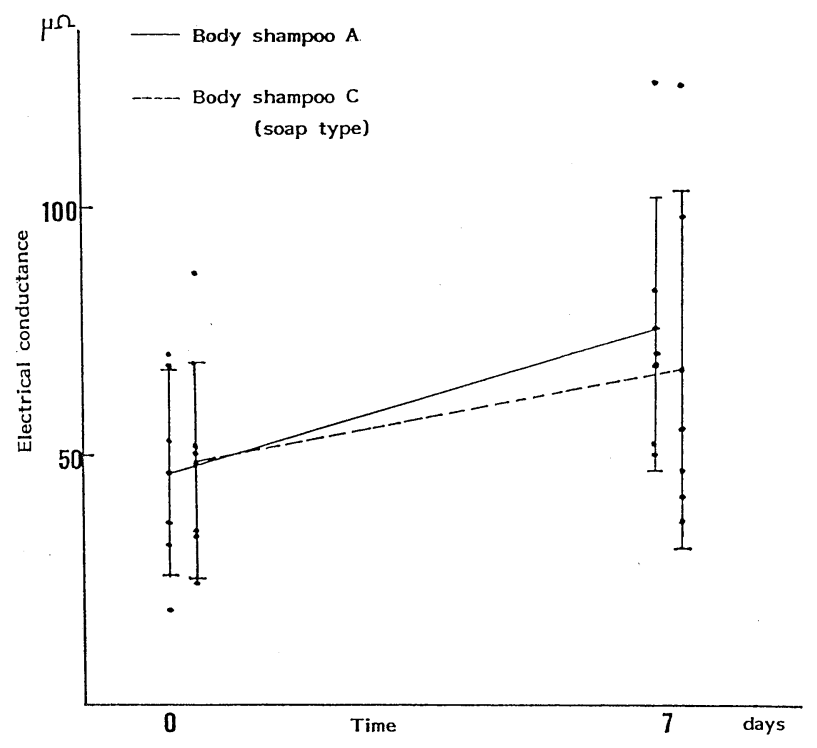

Fig.-14 Changes of Electrical Conductance before and after 1 Week's Use of Two Body Shampoos

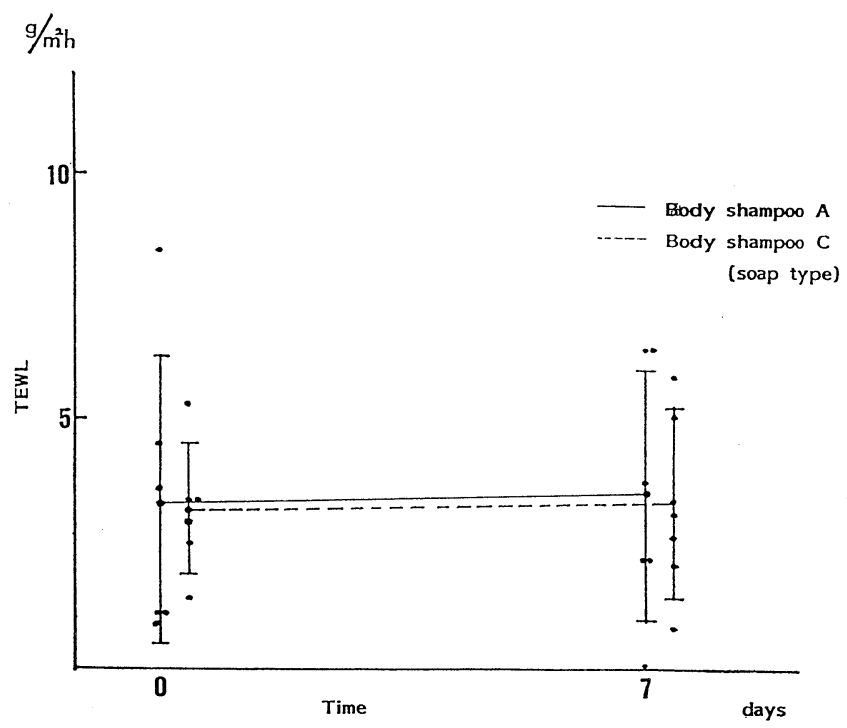

Fig.-15 Changes of Transepidermal Water Loss before and after 1 Week's Use of Two Body Shampoos 
で掬いとり，泡のついた手のひらで全身をそっと なでるよらに指示した。すなわち、タオルその他 で体を摩擦せぬことを遵守させた。この使用法で 市販の石鹼も使用効果を見直す必要があると思 亏。

\section{8. おわりに}

香粧品洗浄剤の皮膚安全性は昔よりはるかによ くなっているが，過剩手入れは禁忌で，肌の状態 に応じたスキンケアが基本である。その使用方法 はできるだけ摩擦をさけるように指導することが 重要だと思う。

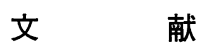

1）須貝哲郎，日皮協ジャーナル，11，31（1988）

2）須貝哲郎, 皮膚, 27, 793 (1985)

3）須貝哲郎, 皮膚, 34, 341 (1992)

4) 須貝哲郎, 皮膚, 34, 496 (1992)

5）須貝哲郎, 皮膚, 33, 19 (1991)

6) Sugai, T., Prog. Internat. Symp. Irritant Contact Dermatitis, 15, Groningen, Holland, Oct. 3-5 (1991)

7）須貝哲郎, 庄司昭伸, 第 8 回日臨皮学会抄録集, 21 , 大阪， 5 月 (1992)

8) Sugai, T., Cutaneous Aging (Kligman, A.M.,
Takase, Y., eds.), Univ. Tokyo Press, Tokyo, 619 (1988)

9) Sugai, T., Hashimoto, Y., Ueda, H., Watanabe, K., Asoh, S., Prog. Clin. Dermatol, in the Year 2000, London, May 22-25, 148, p. 141 (1990)

10) Sugai, T., Preprints of the 1983 IFSCC/SCC Joint Conference on Skin, San Francisco, Sept. 22-23, 12 (1983)

11）須貝哲郎, 皮膚, 23, 206 (1981)

12) Sugai, T., Watanabe, K., Asoh, S., Hashimoto; Y., Shoji, A., Katoh, J., Mita, T., Pediatric Dermatol., 9, 195 (1992)

13）須貝哲郎, 加齢と皮膚（高瀬吉雄，石原 勝，戸 田 浄, 森川藤境編), 丸善, 東京, 141 (1986)

14）山本幸代, 須貝哲郎, 麻生五月, 奥野冨起子, 渡 辺加代子, 山田政春, 皮膚, 26, 517 (1984)

15）流田妙子, 須貝哲郎, 庄司昭伸, 加藤順子, 三田 敏子, 内海美穂子, 中西健史, 持田和伸, 皮膚, 34, 176 (1992)

16） NS 研究班, 日小皮会誌, 6, 146 (1987)

17) Sugai, T., J. Dermatol. Sci., 4, 137 (1992)

18）須貝哲郎, 皮膚病診療, 13，1019, (1991)

19) Rapaport, M. J., Contact Dermatitis, 11, 93 (1984)

（1993年 7 月13日受理） 